\title{
VISITING SCUTTLED SHIPS: AN EXAMINATION OF THE IMPORTANT ELEMENTS OF THE WRECK DIVING EXPERIENCE
}

\author{
ALANA N. SEAMAN* AND GINA L. DEPPER $\dagger$ \\ *Department of Recreation, Sports Leadership \& Tourism Management, \\ University of North Carolina Wilmington, Wilmington, NC, USA \\ †Eppley Institute for Parks and Public Lands, Indiana University, Bloomington, IN, USA
}

\begin{abstract}
Scuba diving is an increasingly popular recreational and tourist pastime. Diving enthusiasts are recognized for their dedication to the sport and willingness to both travel to and spend money on new and unique experiences. Subsequently dive tourism has become a multibillion dollar industry. In turn, many coastal (and other diveable) destinations are investing in the development of local dive sites. However, many popular dive attractions such as naturally occurring coral reefs and historic wrecks are fragile, easily damaged, and/or adversely impacted by visitors. Artificial reefs, or structures purposely sunk to create habitats for marine life and infrastructure for unique diving experiences (often stripped-down large scale pieces of machinery), can draw tourists away from fragile natural ecosystems. Ideally, artificial reefs could also be utilized as underwater cultural heritage management tools similarly drawing visitors away from aging, delicate historic wrecks. However, little is known about wreck divers and/or the wreck diving experience. Thus, the purpose of this study was to examine the specific aspects of the popular purposely scuttled wreck, the USS Spiegel Grove (off the coast of Key Largo) that contributed to visitors' dive experiences. A total of 100 TripAdvisor reviews about the Spiegel Grove were collected and analyzed as data. The majority of reviews were positive and revealed that the size of the ship, the challenge of the dive, the ability to penetrate the ship, the chance to check the dive off a bucket list, and the opportunity to see marine life contributed to divers' experiences. Historic ties were surprisingly of little importance. Although more research is needed, these findings should help destinations to better plan for and design artificial reefs aimed at attracting wreck divers.
\end{abstract}

Key words: Dive tourism; Wreck diving; Underwater heritage; Artificial reefs; Dive experience

Address correspondence to Alana Seaman, SHAHS UNCW, 601 South College Road, C/B 5956, Wilmington, NC 28403, USA. E-mail: SeamanA@uncw.edu 


\section{Introduction}

Scuba diving is an increasingly popular recreational and tourist pastime (Dimmock \& Cummins, 2013). Diving enthusiasts are recognized for their dedication to the sport and willingness to both travel to and spend money on new and unique experiences (Ditton, Osburn, Baker, \& Thailing, 2002; Ditton, Thailing, Riechers, \& Osborn, 2002). Subsequently dive tourism has become a multibillion dollar industry (Eggen, 1997; Garrod \& Gössling, 2008). In turn, many coastal (and other diveable) destinations are investing in the development of local dive sites (Edney \& Spennemann, 2014; Eggen, 1997). In some locations diving has already become a major contributor to the economy (Grier, Christie, \& Amolo, 2017; Huth, Morgan, \& Burkart, 2015; Musa \& Dimmock, 2013; Tynyakov, et al., 2017). However, many popular dive attractions such as naturally occurring coral reefs and historic wrecks are fragile, easily damaged, and/or adversely impacted by visitors (Edney \& Spennemann, 2014; Shackley, 1998). Boats create unnatural noise, exhaust, runoff, and localized currents; errant craft propellers can harm marine life and historic site features; wildlife may change behavior in the presence of divers; inadvertent physical encounters with reefs or antique structures can damage both ecosystems and delicate underwater relics; and the bubbles discharged from divers' air tanks are destructive to both live coral and many antique materials (see, e.g., Edney \& Spennemann, 2014; Jakšić, Stamenković, \& Đorđević, 2013; Shackley, 1998; Smith, Scarr, \& Scarpaci, 2010; Zakai \& Chadwick-Furman, 2002). Artificial reefs, or structures purposely sunk to create habitats for marine life and infrastructure for unique diving experiences (often stripped-down large scale pieces of machinery), can draw tourists away from fragile natural ecosystems (Wilhelmsson, Öhman, Ståhl, \& Shlesinger, 1998). Ideally, artificial reefs could also be utilized as underwater cultural heritage management tools, similarly drawing visitors away from aging, delicate historic wrecks (Edney, 2016). However, little is known about wreck divers and/or the wreck diving experience.

Edney (2011), among others, contended that in order for artificially created wreck sites to be successful both economically and as cultural heritage management tools, there is a need for a better understanding of wreck divers, their motivations and attitudes, and the wreck diving experience itself (see also Kirkbride-Smith, Wheeler, \& Johnson, 2013; Stolk, Markwell, \& Jenkins, 2007). Likewise, site managers and local governing officials working to protect fragile heritage resources would benefit from a better understanding of which features of underwater historic structures are most appealing to divers seeking out shipwrecks (Massin, Norro \& Mallefet, 2002). In this sense, Edney and Spennemann, (2014) called for "more research, particularly qualitative research" that examines the "specific features of artificial reef wrecks that are attractive to divers (i.e. location, type, size and structure of vessel, special features, depth and environmental conditions)" (pp. 106-107).

Thus, the purpose of this study was to examine the specific aspects of the popular purposely scuttled wreck, the USS Spiegel Grove (off the coast of Key Largo) that contributed to visitors' dive experiences (as reported on TripAdvisor during the period of September 6, 2016 through June 10, 2018).

\section{Literature Review}

\section{Diving and Dive Tourism}

Interest and participation in diving has increased steadily over the last 50 years. As a result, diving is now widely recognized as a mainstream marinebased recreational activity (Cater \& Richardson, 2017; Dimmock, 2007; Tzanakis, 2016). The Professional Association of Dive Instructors (PADI), one of the world's largest scuba diver training organizations, averages about 900,000 diver certifications a year, and estimates that they have certified approximately 25 million divers since their inception in 1966 (PADI, 2017). This level of involvement has made diving into a multibillion dollar industry (Ong \& Musa, 2011) and destinations around the globe have worked to attract these tourists by creating artificial reefs (Pendleton, 2005) and underwater dive trails (Rangel et al., 2014), demarcating specific sites as "heritage dive sites" (Kure Beach, 2017), and focusing on marketing and infrastructure development efforts that frame the location as a "must dive" destination (see Tourism Bonaire, 2017, for example). 
In response, many aspects of dive tourism have been considered by scholars including the impacts of dive tourism on local communities (Daldeniz \& Hampton, 2013; Doiron \& Weissenberger, 2014), the health of artificial reef ecosystems compared to natural reef ecosystems (Wilhelmsson et al., 1998) and their impacts on local environments (Eggen, 1997), and the types of marine life divers prefer (Giglio, Luiz, \& Schiavetti, 2015). Several scholars have also attempted to develop frameworks for understanding dive tourism (Dimmock \& Musa, 2015), managing diver impacts on shipwrecks (Edney, 2016; Scott-Ireton, 2005), and sustainable dive tourism development (Wongthong \& Harvey, 2014).

Overall, evidence suggests that divers are largely dedicated, educated, male, somewhat older, moderately wealthy (Ditton, Osburn, et al., 2002; Edney \& Spennemann, 2014; Musa, Kadir, \& Lee, 2006; PADI, 2017), and willing to travel for new and unique diving experiences (K. M. Wong, Thirumoorthy, \& Musa, 2000). Central to the scuba diving experience is risk (Fuchs, Reichel, \& Shani, 2016; Hunt, 1995, 1996; Lee, Tseng, \& Jan, 2015; Tsuar, Lin, \& Cheng, 2015). Risk or the challenge of negotiating the physical and environmental challenges of breathing and navigating under water is the main component of diving that sets the recreational activity apart from other pursuits. Because of the skill and certification required to dive, many scuba divers engage in the activity as a form of serious leisure (Ditton, Thailing, et al., 2002; Stebbins, 2007). Given their commitment, research has shown that divers are, for the most part, knowledgeable about the condition of the reefs they are diving on (Uyarra, Watkinson \& Cote, 2009), and that those who are more specialized act in ways that reduce their impact on the environment (Thapa, Graefe, \& Meyer, 2006). Further, diver satisfaction on artificial reefs was highest among novice divers, but declined with increased experience (Kirkbride-Smith et al., 2013).

\section{Diving Motivation}

Dominating the rather disparate body of research on diving and dive tourism are studies examining diver motivation. Cater (2008) argued that the "primary attraction of the scuba diving experience is immersion in a strange and alien environment” (p. 49). Similarly, Ince and Bowen (2011) found diving to be a highly emotional experience whereas Edney (2012) revealed that divers enjoyed the "peace and tranquility" of diving. A number of studies revealed that divers are primarily motivated to visit specific sites because of the possibility of seeing marine life, which was believed to have contributed to a "good dive" (Kirkbride-Smith et al., 2013; see also Edney, 2011, 2012). Others found that divers were primarily motivated by the social aspects of diving (Bentz, Lopes, Calado, \& Dearden, 2016).

\section{Elements Contributing to the Diving Experience}

The few studies that have explored aspects of the attraction in relation to diver preferences have found a preference for size, location, and depth. Two recent studies of divers found evidence that large reefs or wrecks were more popular than smaller ones (Kirkbride-Smith et al., 2013; Shani et al., 2012) and that among artificial reefs, large naval ships (Kirkbride-Smith et al., 2013; Shani, Polak, \& Shashar, 2012) and airplanes (Shani et al., 2012) were preferred over smaller structures. As for location, nearly $78 \%$ of recreational divers in Eilat, Israel (a well-known and popular dive destination) preferred the artificial reef to be within "relative proximity" of the shore (Shani et al., 2012, p. 373) while in Sipadan (an island in Malaysia) divers were satisfied with a 5-min boat ride to the dive site (Musa, 2002). There also appears to be a preference for depth. In Eilat, approximately 66\% of recreational divers preferred a depth between 15 and $30 \mathrm{~m}$ (about 49 to $98 \mathrm{ft}$ ) (Shani et al., 2012), and dive operators confirmed that a wreck at $21 \mathrm{~m}$ deep received more divers than a wreck at $30 \mathrm{~m}$ deep (Wilhelmsson et al., 1998). In Barbados, 82\% of divers preferred a depth of less than $21 \mathrm{~m}$ (about $69 \mathrm{ft}$ ) (Kirkbride-Smith et al., 2013). Other attributes that made up an enjoyable dive experience included visibility, safety, the amount of coral and fish, and the specific species encountered (Ince \& Bowen, 2011; Kirkbride-Smith et al., 2013).

\section{Wreck Diving}

Although few studies have considered wreck diving as a phenomenon unique from less specialized forms of diving, the activity is becoming 
increasingly popular (Edney, 2016; Edney \& Spennemann, 2014). Evidence suggests that like their more generalized diving counterparts, wreck divers are motivated, in part, to participate in the activity for the opportunity to see marine life and for the peace and tranquility of the underwater experience (Edney, 2012, 2017; Massin et al., 2002). However, wreck diving often requires additional scuba equipment and certification, both of which require a great deal of time and money to acquire. Edney and Spennemann (2014) found that wreck divers (both diving on purposely and historically sunk structures) were educated and high earning, making on average in excess of $\$ 75,000$. Divers also need to be proficient in technical diving skills to ensure they are able to meet the challenges of navigating around and through (penetrating) underwater structural elements and openings. Thus, the motivations for wreck diving and the elements that contribute to wreck divers' satisfaction are thought to be deeper and more nuanced than those influencing other types of divers. Evidence from the handful of studies aimed at understanding wreck divers revealed a strong desire to seek out wrecks with historic ties (Edney, 2011, 2012; Massin et al., 2002) where artifacts could be seen (Edney, 2012; Massin et al., 2002) and divers could "penetrate," or swim through, parts of the underwater structure (Edney, 2012).

\section{Historic Links, Heritage, and Heritage Tourism}

Whereas little else is known about wreck divers, heritage or the use of the past in the present, is an important feature of contemporary tourism in a number of settings (Timothy, 2011; see also Lowenthal, 1998). Fueled by a longing for a "simpler" time in the wake of rapid development, industrialization, and the recent acceleration of technological advancements, tourists are often in search of historically linked experiences that are believed to lend a note of authenticity to the visitor experience (Lowenthal, 1998; Timothy, 2011). Heritage tourism is particularly popular among baby boomers that, upon reaching retirement age, often have more time and expendable income with which to travel (Timothy, 2011).

Nostalgia for images, experiences, and places personally encountered during their adolescence may influence tourists' choice of travel destination and/or the types of activities they engage in while visiting (see, e.g., Davis, 1979). Travel to places of historic relevance and participation in traditional or historically inspired activities is also often undertaken as a means of honoring family ties, cultivating personal identity, and/or reinforcing patriotism and religious connections through shared and vicarious images of nostalgia (Goulding, 2002; Lownethal, 1998; Timothy, 2011). Regardless of the reasons for engaging in heritage tourism whether in pursuit of authentic unique experiences or for deeper more emotional reasons, what qualifies as heritage is subjective, ever-changing, and may encompass any number of relics, traditions, and eras of history (see Lowenthal, 1998; Timothy, 2011).

\section{The Case}

\section{The USS Spiegel Grove}

An artificially created reef with historic relevance, the USS Spiegel Grove served for over 30 years as a US Naval dock landing ship before being decommissioned in 1989 and scuttled 6 miles off the coast of Key Largo, Florida in 2002 (see The Florida Keys, n.d.; Scuba Diving, 2017). During its time as an active military vessel, the ship ran good will missions to various parts of Africa (delivering seed, medical supplies, and food to nations in need), participated in training exercises around the world, served as a support ship during an early 1960s' manned space flight mission, and patrolled the Caribbean for several years (Flatley, 2018). Thousands of naval personnel would have served on the ship over the course of its time at sea, providing untold numbers of decedents personal links to the submerged relic.

After sitting in a mothball fleet in Virginia's James River for over a decade, the ship was scheduled for scuttle on May 18, 2002, but sank unexpectedly $6 \mathrm{hr}$ early, rolling over on its side before landing on the ocean floor (The Florida Keys, n.d.). Efforts to right the sunken vessel failed, but Hurricane Dennis up-righted the boat's hull just a few years later in July 2005 (The Florida Keys, n.d.).

At the time of its sinking, the USS Spiegel Grove was the largest ship ever purposely placed as an artificial reef, and as of 2017 was still the third largest in the world (The Florida Keys, n.d.). Its scale 
and proximity to both Key Largo and other diveable wrecks have made the Spiegel Grove a wellknown dive destination showcased by a number of dive enthusiast media outlets (see, e.g., Meltzer, 2016). Scale aside, due to its depth and enticing but labyrinth-like interior, the scuttled ship has claimed a handful of lives since its rebirth as a dive attraction some 15 years ago (see, e.g., Clark, 2013). Regardless, the ship attracts thousands of divers (and marine life) a year and remains a popular underwater attraction (The Florida Keys, n.d.).

In an attempt to understand the elements of an attraction that contribute to wreck divers' underwater experiences, the USS Spiegel Grove, which exists as both a site with historic ties and as an artificially created reef, is ripe for examination.

\section{Methods}

A content analysis following Babbie (2014) was employed to explore the specific features of the USS Spiegel Grove artificial wreck dive site that contributed to visitors' experiences. Content analysis or "the study of recorded human communications" is a versatile methodology that is meant to allow researchers the flexibility to apply the approach to any number of data sets and topic areas (Babbie, 2014, p. 341). As a form of unobtrusive research, or "learning about human behavior by observing what people inadvertently leave behind them" (Babbie, 2014, p. 340; see also Webb, Campbell, Schwartz, \& Sechrest, 2000), a content analysis methodology is particularly suited to the study of tourism experiences discussed online.

\section{Data Collection}

Data were collected in the form of on-line reviews posted to the popular travel review website TripAdvisor. TripAdvisor, and websites like it, provide a platform for visitors to post short comments, feedback, and first-hand accounts of their experiences at various tourism-related businesses and points of interest. Reviews posted to these types of websites can be considered an example of electronic word of mouth (eWOM) (Cantallops \& Salvi, 2014: Litvin, Goldsmith, \& Pan, 2008). As user created data, eWOM is often perceived as more reliable and truthful than those dialogs communicated by experts, because it is presumed to have been written about real experiences, by real travelers, who have not been compensated for their reviews (Ayeh, 2015; Ayeh, Au, \& Law, 2013). Thus, it is a popular component of pretrip and during trip research for many travelers (Leung, 2011; Miguéns, Baggio, \& Costa, 2008).

On-line reviews can influence potential travelers by impacting both where tourists choose to visit and which activities they choose to engage in while visiting (Jalilvand \& Samiei, 2012; Litvin et al., 2008; Sparks \& Browning, 2011). Several studies suggest that over half, and possibly as many as two thirds, of all web users consult the Internet before making travel decisions and purchases (O’Connor, 2010; Pan, Maclaurin \& Crotts, 2007). When searching the web for information about a destination, Xiang and Gretzel (2010) found that social media sites and user-generated content sites (or review-based websites) were among the top results produced by a number of the most popular Internet search engines. Thus, eWOM or online reviews, like various other narratives and images in popular culture, contribute to the ways in which people see locations as distinctive destinations (Lefebvre, 1992; Taun, 1974; see also Seaman, 2016), and work, in part, to inform potential visitors about the activities that can (and should) be engaged in while visiting a location (Goffman, 1959; Rickly-Boyd, Knudsen, Braverman \& Metro-Roland, 2014; Seaman, 2016). In short, eWOM encountered on websites such as TripAdvisor mold how both specific attractions and whole destinations are perceived and engaged with (see, e.g., Jalilvand, Ebrahimi, \& Samiei, 2013; Leung, 2011; O’Connor, 2008, 2010). Thus, an analysis of the types of comments potential visitors are likely to encounter when exploring a trip to the USS Spiegel Grove can provide researchers with an idea of how future visitors are likely to perceive, and in turn, engage with the underwater attraction.

In addition to their popularity among travelers, on-line review websites like TripAdvisor provide researchers with an easily accessible and uniquely candid user-generated data source. As visitors can provide unbiased, up-to-date reviews, with no incentives for their contribution other than knowing their review may be read by others, the availability of the reviews and often blunt nature of the comments posted provides researchers with a data 
source ripe for examination (Litvin et al., 2008; Sparks \& Browning, 2011; O’Connor, 2008, 2010). Although there is no way to ensure the accuracy of the reviews, or to tell when the reviews were posted relative to the reviewer's experience, O'Connor (2008) found that fears about the lack of credibility of online reviews was largely unfounded. Essentially, travel reviews provide researchers a rich data source from which to gain a large amount of unsolicited qualitative data generated by a presumably representative population sample (Litvin et al., 2008; Owens, 2012; Pan, Maclaurin, \& Crotts, 2007; Sparks \& Browning, 2011). eWOM has been utilized as a data source in numerous tourism studies from examinations of sporting event fan experiences (Wakefield \& Bennett, 2018), and explorations of how heritage attractions in New York State are being portrayed as a whole (Pepe \& Bournique, 2017), to investigations of the evolution of destinations such as Macau (C. U. Wong \& Qi, 2017) and various cities in Iran (Jalilvand et al., 2013). TripAdvisor, in particular, given its position as the most prominent travel review website, has been used by scholars to study perceptions of Charleston as a travel destination (Pan et al., 2007); how visitors view hotels in London (O'Connor, 2008); and how hotels respond to online reviews in order to curate and maintain a particular image of their establishment (O’Connor, 2010).

For this study, the 100 most recent reviews posted to the TripAdvisor page on the USS Spiegel Grove dive site as of June 12, 2018 comprised the data set. All reviews were posted to the website between September 6, 2016 and June 10, 2018.

\section{Data Analysis}

The data set was first analyzed using an open coding approach. At this stage, the data were explored with little expectation about what might be found (Babbie, 2014). Upon this initial examination of the data, descriptive codes were developed. If a review included more than one element contributing to the wreck diving experience, then all codes were recorded (Kvale \& Brinkman, 2009). Codes were noted but given little further consideration at this stage (see Miles \& Huberman, 1994). Once recorded, the data set was examined again with initial codes in mind and several themes began to emerge. To further develop these themes, codes were considered in combination and in contrast to one another (see Babbie, 2014). Employing a latent content coding technique aimed at going beyond a simple count of notable terms, analysis intended to understand the meaning, or essence, of the reviews examined (Babbie, 2014; see also Corbin \& Strauss, 2007; Moustakas, 1994).

Each theme was then considered in depth, and a focus was placed on examining each concept from various angles. Babbie (2014) called this reexamination of the initial coding stage axial coding and contended this type of analysis is when core concepts are identified. This inductive approach is meant to allow for the development of multiple themes wherein researchers are provided with an array of answers to their research question, resulting in a multifaceted understanding of the subject at hand (Creswell, 2014).

This approach led to the development of overarching themes and specific codes describing them, when available. The themes and codes were then quantified to better understand the frequency with which specific elements of the wreck resonated with reviewers as influential on their experience (Kvale \& Brinkman, 2009). When a review aligned with a theme, but did not have enough specificity for a code, it was counted only at the theme level.

\section{Validity and Reliability}

To ensure the validity and reliability of the study, both contradictory and alternative explanations for the themes developed were considered (see Babbie, 2014). Further, reflexivity exercises were engaged in to ensure inherent researcher bias was identified and efforts made to ensure it did not impact the study's findings (see Creswell, 2014). Finally, steps were taken to record the progression of theme development as data analysis was under way. This detailed memoing is helpful in allowing for the replication of the study which Babbie (2014) pointed out is important in solidifying the reliability of the research and its findings (see also Miles \& Huberman, 1994).

\section{Findings}

The data analysis revealed six overarching themes: 1) Size of the ship, 2) Challenge of the dive, (3) Swim through/penetration, (4) Wildlife/ 
Table 1

Themes and Codes by Frequency

\begin{tabular}{lc}
\hline Theme and Codes & Frequency \\
\hline Size of ship & \\
Magnitude & 31 \\
Multiple dives & 21 \\
Challenge of dive & 7 \\
Depth & 19 \\
Currents & 18 \\
Poor visibility & 11 \\
Swim through/penetrations & 32 \\
Snoopy & 3 \\
Wildlife/nature & 34 \\
Heritage & 2 \\
American flag & 9 \\
Bucket list & 4 \\
\hline
\end{tabular}

nature, (5) Heritage, and (6) Bucket list and their accompanying codes (Table 1). The vast majority of reviews were positive and visitors reported enjoying many aspects of their dive experiences at the USS Spiegel Grove.

\section{Size}

The shear size of the sunken ship was widely and enthusiastically mentioned as an impactful characteristic of the dive site among the data set. Visitors reported being surprised by the "ginormity" of the vessel. "This wreck is absolutely HUGE," wrote one visitor, capturing the popular notion. "When I first got on the ship," the reviewer went on, "I could see that it was big. What I didn't realize was that what I thought was the sand was actually the hold filled with sand from Hurricane Irma! When I saw the other side of the ship, I realized how immense it actually is!!”

At over $500 \mathrm{ft}$ long and $80 \mathrm{ft}$ wide, the enormous craft enticed many visitors to return day after day for multiple dives on the site, noting that there was "always something new to explore," "You could spend weeks and not see it all," pointed out one reviewer while another explained, "it would take you a week of diving to explore every nook and cranny." Others enjoyed the variability of conditions and diversity of sea life encountered on each visit. Even self-reported locals agreed; one reviewer's glowing review read, "We dive this wreck every couple of weeks because the life on it changes all the time.” This confirms the findings of
Ditton, Osburn, et al. (2002), who found that divers preferred large underwater structures.

\section{Challenging Dive}

Varying elements pertaining to the challenge of the dive were similarly widely mentioned. While the size of the ship was impressive to reviewers, the temptation to spend time exploring the site can be dangerous and has claimed the lives of a handful of visitors since its scuttling in 2002. The deck of the massive vessel sits some $60 \mathrm{ft}$ below the oceans' surface, making descending and, more importantly, ascending time consuming. Its depth requires divers to properly calculate their air needs prior to submerging and failure to do so can have deadly consequences. However, reviewers were well aware of the risks. A number of posts suggested that visitors plan to dive with "nitrox," an oxygen-enriched air supply that allows divers to expedite the decompression and ascent process (Ange, 2017) to extend their time on the submerged structure. Statements on the subject, such as "Nitrox is a good idea as well to ensure maximum bottom time," were largely causal in nature, and clearly aimed at offering future divers the chance to enjoy the site as thoroughly as possible, not posted as dire warnings.

In addition to the scale and depth of the ship, other challenging aspects of diving on the USS Spiegel Grove were depicted as largely positive (simply obstacles to be conquered), with the exception of the unpredictable currents, which resulted in low visibility on and around the artificial reef. Indicative of impacts that the conditions had on divers was one reviewer who posted, "Be advised, that conditions can vary daily from great visibility and zero current to poor viz and strong currents to anything in between.” Others similarly noted how the currents had foiled their dive plans: "This was my fourth time on this dive and only the second without a ripping current" read one post while another explained how even mid-dive, "this wreck can be quickly overtaken by strong currents and poor visibility."

The challenge of getting down to the ship in moderate currents, and navigating the multitude of dive guide lines and active fishing lines (as boats are still permitted to, and often do, fish the wreck while divers tour the scuttled vessel below) also impacted 
divers experiences on the wreck. "Beware of fish lines and hooks," advised one reviewer, highlighting the hurdles associated with diving on the USS Spiegel Grove, “the wreck is fished whilst you're diving it. Last but certainly not least: Bring some gloves, the mooring lines have razor sharp clams in/on them and you might find the odd fishing hook in the line.” Despite the warnings, like many others, the reviewer proclaimed it a "Great dive, but come prepared!”

\section{Swim Through/Penetration}

Swimming through portions of the ship also contributed to the experiences of a number of visitors. Divers reported enjoying the "plenty of safe passages that you can explore with minimal danger." Swimming through, or entering an underwater feature, is known as "penetration" and requires divers to have special training and in some cases additional certifications (Scuba Diving, 2006). The labyrinthlike interior of the ship can prove precarious if divers are not prepared for an extended amount of time under water, or are unfamiliar with the layout of the large vessel. In light of the risks involved, a handful of reviews echoed warnings similar to the ones that read: "you can penetrate the wreck at some points, but make sure you know what you're doing before you do," and "While there is plenty to explore for the newer divers, be careful, because there are plenty of places to enter that you shouldn't without the proper training."

Overcoming the challenge of penetrating the ship was a point of pride for a number of divers. Many offered glowing reviews about how much they enjoyed their own experiences, noting things like "the swim throughs are incredible" before lamenting on the expertise needed to safely enjoy the ship. "I would recommend you being a fairly competent diver to see this beauty," noted one reviewer after sharing details of his dive much like what others had also posted.

Elevating the experience for a handful of reviewers was the challenge of searching for a painting of the comic strip character Snoopy, located inside the ship. The painting, often covered in a thick layer of silt, is not an easy to locate icon. "We penetrated many levels and got to see the Snoopy Mascot and a huge Goliath Grouper,” gushed one reviewer while another enjoyed their dive, noting that they "saw a lot of the boat, but couldn't find the entrance to the Snoopy hallway," conceding happily that “we'll have to go back." Oddly, there were no mentions of the origin of the painting, its significance, or the Snoopy icon's meaning.

\section{Nature/Wildlife}

Visitors also frequently reported exciting and memorable encounters with sea life. Divers were excited to see the variety of fish, coral, and reptiles that frequent the site. Reviews reflected an admiration for both the number and variety of species that could be seen. "This dive site is a fully developed reef ecosystem," wrote one reviewer, "luscious coral covers the huge cranes and the gun mounts and carpets all of the decks, plentiful reef creatures inhabit the nooks and crannies of the vessel.” For others, the presence of specific species added to the enjoyment of their visit. "We saw a turtle and a frog fish,” wrote one reviewer. Others marveled at their encounters with "a loggerhead (sic) turtle and a shoal of large barracuda," "a goliath grouper," and "a green moray eel [that] slithered around which was the highlight of our whole week of diving." In this sense, divers enjoyed the notion that there was "always a surprise of what marine life you may find." Although nature and wildlife were mentioned in many of the reviews, they were often noted second to other themes and codes.

\section{Heritage}

Despite recent research that found that people were motivated to dive on wrecks by historic ties (Edney, 2011, 2012; Massin et al., 2002), it is notable that only one review in this data set made mention of the ship as a craft with any historic relevance. The review simply read "the USS Spiegel Grove! A US Navy ship a few minutes from shore. WOW!” thus recognizing the ship as relevant to American military history, but failing to identify any specific historic aspects. Although the ship did not engage in any particularly significant historic events, it was a long-serving vessel in the U.S. Navel fleet that would have been manned by hundreds if not thousands of sailors during its tenure at sea. Yet there were no mentions of personal or ancestral ties to 
the ship, or even references to historic images in popular culture. Rather, the presence of an American Flag "flying" in the underwater current was a highlight for many visitors, providing them with a unique experience and significant photo opportunity. "Seeing the American flag waving in the current was spooky as hell," posted one visitor capturing the awe that others had also expressed.

\section{Bucket List}

Diving the USS Spiegel Grove was a long-held and lofty goal for a few reviewers and many reported waiting a long time and traveling great distances just to dive the site. "I have been waiting to dive this wreck for months. Finally, the stars aligned and we got to go!"; "I finally got to dive her" and similar comments reflected tourists' sustained enthusiasm for visiting. Several reviewers even stated that diving the massive wreck was on their "bucket list.” Though reviewers did not delve into or articulate exactly why the Spiegel Grove held such a high place on their travel aspirations or exactly why the wreck had tempted them in ways other dive sites had not, divers who had long desired to visit were not disappointed, exclaiming upon their experience that they "LOVE this wreck," and proclaiming it a "very cool dive," an "outstanding dive," "amazing first deep dive," and a "must dive."

\section{Conclusions}

Overall, findings suggest that the size and challenges associated with diving on the USS Spiegel Grove were the primary aspects of the site that visitors derived enjoyment from. This aligns with research on diver preferences in Israel (Shani et al., 2012) and Barbados (Kirkbride-Smith et al., 2013), which also found that the size of the wreck was important. Kirkbride-Smith et al. (2013) proposed that the size of an attraction is important to divers because it allows them to maximize their underwater experience within the limited time frames dictated by their air supply. This seemed to be true for the USS Spiegel Grove as reviewers noted that it was so big that they had to come back for multiple dives. This point has merit in that a large vessel that takes time to explore minimizes the opportunity for boredom and likely makes the visitor feel as if they received the full value for their dive. Size is probably also a key aspect of the experience because the larger the wreck, the further opportunity for exploration. Kaplan, Kaplan, and Ryan (1998) identified exploration and understanding as the two basic needs people have in their environment. In studies of environmental preferences, people have preferred environmental elements that allow them to explore and gain more information about their surroundings (Kaplan et al., 1998). A large ship like the USS Spiegel Grove meets this basic need and, as found in this study, led to repeat visits. This is valuable information for destinations considering the development of an artificial reef, because repeat visits translate into economic support for the tourism industry.

Further, the results from this study highlighted several challenges that visitors seemed to enjoy overcoming. For instance, while the depth of the USS Spiegel Grove at $60 \mathrm{ft}$ (about $18 \mathrm{~m}$ ) was an obstacle, visitors enjoyed sharing with others the strategies they had used to overcome it. Their appreciation of the depth of the Spiegel Grove is consistent with the preferred depths of divers in other locations (Kirkbride-Smith et al., 2013; Shani et al., 2012). Currents and visibility were other noted elements that increased the challenge of the dive. While most visitors mentioned the challenges associated with the variability of currents and visibility at the Spiegel Grove, one diver wrote several posts implying that they had continued to visit the wreck specifically to overcome those difficulties. Ince and Bowen (2011) found current and visibility to generally detract from an enjoyable diving experience, but as seemed to be the case in this study, a few divers in their study found it exhilarating to overcome. Navigating fishing lines was also identified as a challenge, and although the divers of the USS Spiegel Grove were more neutral in their comments than upset, Edney (2017) found that wreck divers in Australia and Micronesia felt that some wrecks should be zoned to exclude fishing and other uses to ensure a safe and enjoyable experience for all visitors. These findings suggest that destinations providing multiple opportunities for recreation might need to consider management strategies such as zoning for other users if they plan to have divers as their target market. Overall, the challenges that visitors to the Spiegel Grove enjoyed overcoming 
are likely linked to individual social capital and ultimately identity. The ability of the wreck divers to share stories with others and the recognition of what they themselves have achieved builds selfesteem and no doubt contributes to perceptions of who they are (Cater, 2008). This is an invaluable outcome of the experience and perhaps a reason that many wreck divers enjoy the opportunity to overcome challenges during their dives.

Other elements of the USS Spiegel Grove that contributed to wreck divers' experience included the opportunity to penetrate or swim through the ship, the chance to check the dive off their bucket list, and an opportunity to see marine life. The satisfaction derived from the opportunity to explore the ship aligns with the findings of Edney (2012) and Kirkbride-Smith et al. (2013), who also found that wreck divers enjoyed the opportunity to penetrate the ship. The chance to explore also fulfills the human preference to know and understand the environment (Kaplan et al., 1998). The specific aspect of the Snoopy drawing within the wreck adds another element of interest and challenge to penetrating the ship. The inability of one visitor to find Snoopy led them to state that they would return to try again. With this is mind, destinations working to draw repeat visitors could identify or even create unique features on or in underwater attractions to both spark a renewed interest in the site and increase the challenges associated with the site. Both aspects could also be touted in marketing materials to frame the dive attraction as uniquely enticing to divers of all capabilities.

Similar to research that identified marine life as a motivating factor for divers (Bentz et al., 2016; Edney, 2017) and a key piece in creating comfortable and enjoyable diving experiences (Dimmock, 2009; Ince \& Bowen, 2011), this study found that marine life was important to many wreck divers' experiences. Reviewers largely appreciated the amount of sea life as well as specific large or charismatic species. These findings are consistent with a variety of studies (Giglio et al., 2015; Ince \& Bowen, 2011; Kirkbride-Smith et al., 2013; Musa, 2002). Cater (2008) made a connection between research on the "big five" species visitors go to see and expect to see in Africa and the many marine species divers might expect and desire to see when visiting reefs. Destinations might consider this in marketing and make an effort to advertise any charismatic or unique species their site has to offer.

The influence of marine life on wreck divers' experience is important to note because it requires destinations to manage wreck diving sites in a way that ensures the integrity of the resources. Further, the experience of viewing marine life could also motivate wreck divers to become active in resource conservation. Ballantyne, Packer, and Sutherland (2011) found that participants involved in a variety of marine-based wildlife tourism experiences developed an emotional connection to the species they viewed. Participants who reflected on these types of experiences developed a concern for the species as a whole (Ballantyne et al., 2011). Underwater encounters with marine life could potentially result in a similar desire to want to get involved in the protection and preservation of aquatic resources. Future research may want to consider the affective aspects of the wreck diving experience.

Overall, the unique diving experience created by the wreck was of greater importance to divers than the ship's historic significance. Surprisingly the ship's historic links and features were hardly mentioned within the data set. In this sense, there was little indication that visitors were engaging in heritage tourism or had any interest in the ship's history. These findings come in stark contrast to previous studies that found heritage to be of great importance to wreck divers (Edney, 2011, 2012; Massin et al., 2002) and should be confirmed by future studies.

Regardless, destinations considering investing in local dive sites will find this information useful. Instead of investing in the scuttling of craft of historic significance, or pursuing marketing efforts capitalizing on an existing feature's cultural importance for example, dive destinations (such as the newly opened Heritage Dive Site at Fort Fisher) may find that money is better spent on improving and advertising the unique aspects of the underwater experience itself. Further, coastal (and other diveable destinations) may consider investing in the scuttling of structures that create unique diving experiences rather than pursuing historically relevant artifacts that often come with a higher price tag, additional decontamination requirements, and additional bureaucratic processes to acquire (see Pendleton, 2005). In other words, why invest in a 
vessel of historic significance when a destination could just as easily sink an old Buick or other large but insignificant and therefore much more affordable piece of machinery?

This study represents feedback from only one dive site and travel review platform, and more research is needed to both confirm and build upon the results of this study. Nonetheless, the findings revealed provide researchers with a place to start, and qualitative data from which future surveys and other qualitative and quantitative studies could be developed. Given the increasing popularity of wreck diving, and scuba diving more generally, more research is needed to understand this economically, environmentally, and culturally significant form of tourism.

\section{Biographical Notes}

Alana Seaman is an Assistant Professor of Recreation, Sports Leadership, and Tourism Management within the School of Health and Applied Human Sciences at the University of North Carolina Wilmington. She earned her Ph.D. in Parks, Recreation, and Tourism Management from Clemson University where her dissertation research examined the connections between literature, place, and tourist performance (or what people "do" while traveling). Today her research interests are still focused on the links between popular culture (particularly literature, film, and television) and tourism, heritage tourism, semiotics, place-making, tourist performance, and humanistic geography. Dr. Seaman was recently appointed Secretary/Treasurer of the Media and Communications Specialty Group of the American Association of Geographers.

Gina Depper is an Assistant Research Scientist with the Eppley Institute for Parks and Public Lands in the Department of Recreation, Park and Tourism Studies at Indiana University. She received her doctorate from the Department of Parks, Recreation and Tourism Management at Clemson University where she studied the transmission of environmental values from influential sources to young adults. She specializes in the human dimensions of natural resource management to develop stewardship for the environment and improve land management decision-making and capacity. Specifically, she studies environmental values frameworks, environmental values transmission, perceptions, attitudes, and preferences regarding park and recreation areas and entities, and organizational planning and training needs. At the Eppley Institute she manages research and planning, focusing on employee training needs assessments, cooperative agreements among land management agencies, program evaluations, and planning for parks and recreation agencies.

\section{References}

Ange, M. (20 December 2017). Practical guide to nitrox diving. Scuba Diving. Retrieved from https://www.scuba diving.com/nitrox-scuba-diving-guide-certification

Ayeh, J. K. (2015). Travellers' acceptance of consumergenerated media: An integrated model of technology acceptance and source credibility theories. Computers in Human Behavior, 48, 173-180.

Ayeh, J. K., Au, N., \& Law, R. (2013). "Do we believe in TripAdvisor?” Examining credibility perceptions and online travelers' attitude toward using user-generated content. Journal of Travel Research, 52(4), 437-452.

Babbie, E. (2014). The basics of social research. Belmont, CA: Wadsworth.

Ballantyne, R., Packer, J., \& Sutherland, L. A. (2011). Visitors' memories of wildlife tourism: Implications for the design of powerful interpretive experiences. Tourism Management, 32(4), 770-779.

Bentz, J., Lopes, F., Calado, H., \& Dearden, P. (2016). Understanding diver motivation and specialization for improved scUBa management. Tourism in Marine Environments, 12(1), 35-49.

Cantallops, A. S., \& Salvi, F. (2014). New consumer behavior: A review of research on eWOM and hotels. International Journal of Hospitality Management, 36, 41-51.

Cater, C. (2008). Perceptions of and interactions with marine environments: Diving attractions from great whites to pygmy seahorses. In B. Garrod \& S. Gossling (Eds.), New frontiers in marine tourism: Diving experiences, sustainability, management (pp. 49-64). Oxford, UK: Elsevier.

Cater, C., \& Richardson, S. (2017). Marine and coastal tourism. In D. R. Green \& J. L. Payne (Eds.), Marine and coastal resource management: Principles and practice. New York, NY: Routledge.

Clark, C. (2013, October 18). Missing diver found dead in the wreck of the USS Spiegel Grove in the keys. Miami Herald. Retrieved from https://www.miamiherald.com/ latest-news/article1956430.html

Corbin, J. M. \& Strauss, J. M. (2007). Basics of qualitative research: Techniques and procedures for developing grounded theory. Thousand Oaks, CA: Sage.

Creswell, J. W. (2014). Research design: Qualitative, quantitative, and mixed methods approaches. Thousand Oaks, CA: Sage.

Daldeniz, B., \& Hampton, M. P. (2013). Dive tourism and local communities: Active participation or subject to impacts? Case studies from Malaysia. International Journal of Tourism Research, 15(5), 507-520.

Davis, F. (1979). Yearning for yesterday: A sociology of nostalgia. New York, NY: Free Press.

Dimmock, K. (2007). Scuba diving, snorkeling and free diving. In G. Jenning (Ed.), Water-based tourism, sport, leisure, and recreation experiences (pp. 128-148). Amsterdam, The Netherlands: Butterworth-Heinemann.

Dimmock, K. (2009). Finding comfort in adventure: Experiences of recreational SCUBA divers. Leisure Studies, 28(3), 279-295. 
Dimmock, K., \& Cummins, T. (2013). History of scuba diving tourism. In G. Musa \& K. Dimmock (Eds.), Scuba diving tourism (pp. 14-28). Abingdon, UK: Routledge.

Dimmock, K., \& Musa, G. (2015). Scuba diving tourism system: A framework for collaborative management and sustainability. Marine Policy, 54, 52-58.

Ditton, R. B., Osburn, H. R., Baker, T. L., \& Thailing, C. E. (2002). Demographics, attitudes, and reef management preference of sport divers in offshore Texas waters. ICES Journal of Marine Science, 59(Suppl), S186-S191.

Ditton, R. B., Thailing, C. E., Riechers, R. K., \& Osburn, H. R. (2002). The economic impacts of sport divers using artificial reefs in Texas offshore waters. $53^{\text {rd }}$ Gulf and Caribbean Fisheries Institute.

Doiron, S. \& Weissenberger, S. (2014). Sustainable dive tourism: Social and environmental impacts-The case of Roatan, Honduras. Tourism Management, 10, 19-26.

Edney, J. (2011, November). Understanding wreck divers: Case studies from Australia and Chuuk Lagoon. In Proceedings on the Asia-Pacific Regional Conference on Underwater Cultural Heritage (pp. 575-587).

Edney, J. (2012). Diver characteristics, motivations, and attitudes: Chuuk Lagoon. Tourism in Marine Environments, 8(1-2), 7-18.

Edney, J. (2016). A framework for managing diver impacts on historic shipwrecks. Journal of Maritime Archaeology, 11(3), 271-297.

Edney, J. (2017). Human dimensions of wreck diving and management: Case studies from Australia and Micronesia. Tourism in Marine Environments, 12(3-4), 169-182.

Edney, J., \& Spennemann, D. H. (2014). Can artificial reefs reduce impacts on historic shipwrecks? Perceptions and motivations held by wreck divers. Journal of the Australasian Institute for Maritime Archaeology, 38, 93.

Eggen, M. (1997). That sinking feeling: Do "artificial reefs” in BC waters increase biodiversity or waste? Alternatives Journal, 23(1), 7.

Flatley, K. (2018). The history of the USS Spiegel Grove. Kevin Flatley. Retrieved from https://www.kevinflatley. com/lsd-32.htm

Fuchs, G., Reichel, A., \& Shani, A. (2016). Scuba divers: The thrill of the risk or the search for tranquility. Tourism Recreation, 41(2), 145-156.

Garrod, B., \& Gossling, S. (Eds.). (2007). New frontiers in marine tourism. New York, NY: Routledge.

Giglio, V. J., Luiz, O. J., \& Schiavetti, A. (2015). Marine life preferences and perceptions among recreational divers in Brazilian coral reefs. Tourism Management, 51, 49-57.

Goffman, E. (1959). The presentation of self in everyday life. New York, NY: Anchor Books.

Goulding, C. (2002). An exploratory study of age related vicarious nostalgia and aesthetic consumption. Advances in Consumer Research, 29, 542-546.

Grier, L., Christie, P., \& Amolo, R. (2017). Community perceptions of scuba dive tourism development in Bien Unido, Bohol Island, Philippines. Journal of Coastal Conservation, 21(1), 153-166.
Hunt, J. C. (1995). Divers' accounts of normal risk. Symbolic Interaction, 18(4), 439-462.

Hunt, J. C. (1996). Diving the wreck: Risk and injury in sport scuba diving. The Psychoanalytic Quarterly, 65(3), 591-622.

Huth, B., Morgan, A., \& Burkart, C. (2015). Measuring Florida artificial reef economic benefits: A synthesis. Presented at Florida Artificial Reef Summit, Clearwater, Florida, USA.

Ince, T., \& Bowen, D. (2011). Consumer satisfaction and services: Insights from dive tourism. The Service Industries Journal, 31(11), 1769-1792.

Jakšić, S., Stamenković, I., \& Đorđević, J. (2013). Impacts of artificial reefs and diving tourism. Turizam, 17(4), 155-165.

Jalilvand, M. R., Ebrahimi, A., \& Samiei, N. (2013). Electronic word of mouth effects on tourists' attitudes toward Islamic destinations and travel intention: An empirical study in Iran. Procedia - Social and Behavioral Sciences, 81, 484-489.

Jalilvand, R. M., \& Samiei, N. (2012). The impact of electronic word of mouth on a tourism destination choice. Internet Research, 22(5), 591-612.

Kaplan, R., Kaplan, S, \& Ryan, R. L. (1998). With people in mind: Design and management of everyday nature. Washington, DC: Island Press.

Kirkbride-Smith, A. E., Wheeler, P. M., \& Johnson, M. L. (2013). The relationship between diver experience levels and perceptions of attractiveness of artificial reefsexamination of a potential management tool. PLoS One, 8(7), e68899.

Kure Beach. (2017, July 10). First North Carolina heritage dive site dedicated at Fort Fisher near Kure Beach. Retrieved from https://www.wilmingtonandbeaches.com/ kure-beach/about/news-blogs/post/first-north-carolinaheritage-dive-site-dedicated-at-fort-fisher-near-kurebeach/

Kvale, S., \& Brinkman, S. (2009). InterViews: Learning the craft of qualitative research interviewing (2nd ed.). Thousand Oaks, CA: Sage Publications, Inc.

Laing, J., \& Frost, W. (2014). Explorer travellers and adventure tourism. Bristol, UK: Challenge View Publications.

Lee, T. H., Tseng, C. H., \& Jan, F. H. (2015). Risk-taking attitude and behavior of adventure recreationists: A review. Journal of Tourism \& Hospitality, 4(149), 1-3.

Lefebvre, H. (1992). The production of space. Hoboken, NJ: Wiley-Blackwell

Leung, D. (2011). The perceived destination image of Hong Kong on Ctrip.com. International Journal of Tourism Research, 13(2), 124-140.

Litvin, S. W., Goldsmith, R. E., \& Pan, B. (2008). Electronic word-of-mouth in hospitability and tourism management. Tourism Management, 29(3), 458-468.

Lowenthal, D. (1998). The heritage crusade and the spoils of history. Cambridge, UK: Cambridge University Press.

Massin, C., Norro, A., \& Mallefet, J. (2002). Biodiversity of a wreck from the Belgian Continental Shelf: monitoring using scientific diving: preliminary results. Bulletin 
van het Koninklijk Belgisch Instituut voor Natuurwetenschappen, Biologie, 72, 67-72.

Meltzer, M. (28 July 2016). Beautifully eerie shipwrecks near the US you can actually dive in. Thrillist. Retrieved from https://www.thrillist.com/travel/nation/best-shipwreck-diving-in-the-usa-mexico-the-caribbean-sea

Miguéns, J., Baggio, R., \& Costa, C. (2008). Social media and tourism destinations: TripAdvisor case study. Advances in Tourism Research, 26(28), 1-6.

Miles, M. B., \& Huberman, A. M. (1994). Qualitative data analysis. Thousand Oaks, CA: Sage.

Moustakas, C. (1994). Phenomenological Research Methods. Thousand Oaks, CA: Sage.

Musa, G. (2002). Sipadan: A SCUBA-diving paradise: An analysis of tourism impact, diver satisfaction and tourism management. Tourism Geographies, 4(2), 195-209.

Musa, G., Kadir, S. L. S. A., \& Lee, L. (2006). Layang Layang: An empirical study on SCUBA divers' satisfaction. Tourism in Marine Environments, 2(2), 89-102.

Musa, G., \& Dimmock, K. (Eds.). (2013). Scuba diving tourism. (Vol. 40). New York, NY: Routledge.

O’Connor, P. (2008). User-generated content and travel: A case study on TripAdvisor.com. In P. O’Connor, W. Höpken, \& U. Gretzel (Eds.), Information and Communications Technologies (pp. 47-58). Vienna, Austria: Springer.

O’Connor, P. (2010). Managing a hotel's image on TripAdvisor. Journal of Hospitality Marketing \& Management, 19(7), 754-772.

Ong, T. F., \& Musa, G. (2011). An examination of recreational divers' underwater behavior by attitude-behavior theories. Current Issues in Tourism, 14(8), 779-795.

Owens, T. (2012). TripAdvisor rates Einstein: Using the social web to unpack the public meanings of a cultural heritage site. International Journal of Web Based Communities, 8(1), 40.

Pan, B., Maclaurin, T., \& Crotts, J. C. (2007). Travel blogs and the implications for destination marketing. Journal of Travel Research, 46(1), 35-45.

Pendleton, L. H. (2005). Understanding the potential economic impacts of sinking ships for SCUBA recreation. Marine Technology Society Journal, 39(2), 47-52.

Pepe, M. S., \& Bournique, R. (2017). Using social media as a historical marketing tool for heritage sites in eastern New York State. The Journal of Applied Business Research, 33(1), 123-134.

Professional Association of Dive Instructors. (2017). Worldwide corporate statistics 2017: Data for 2011-2016. Retrieved from https://www.padi.com/sites/default/files/ documents/2017\%20PADI\%20WW\%20Statistics.pdf

Rangel, M. O., Pita, C. B., Gonçalves, J. M. S., Oliveira, F., Costa, C., \& Erzini, K. (2014). Developing selfguided scuba dive routes in the Algarve (Portugal) and analysing visitors' perceptions. Marine Policy, 45, 194-203.

Rickly-Boyd, J. M., Knudsen, D. C., Braverman, L. C., \& Metro-Roland, M. C. (2014). Tourism, performance \& place. Surrey, UK: Ashgate.
Scott-Ireton, D. (2005). Preserves, parks, and trails: Strategy and response in maritime culture resource management (Ph.D. thesis). Florida State University, Tallahassee, FL.

Scuba Diving. (2006). Penetrating questions. Scuba Diving. Retrieved from https://www.scubadiving.com/training/ basic-skills/penetrating-questions

Scuba Diving. (2017). Dive Key Largo's U.S.S. Spiegel Grove. Scuba Diving. Retrieved from https:/www.scuba diving.com/dive-key-largos-uss-spiegel-grove

Seaman, A. N. (2016). Exploring the connections between literary places, literary texts, and tourist performance (Ph.D. dissertation). Clemson University, Clemson, SC.

Shackley, M. (1998). 'Stingray City'-managing the impact of underwater tourism in the Cayman Islands. Journal of Sustainable Tourism, 6(4), 328-338.

Shani, A., Polak, O., \& Shashar, N. (2012). Artificial reefs and mass marine ecotourism. Tourism Geographies, 14(3), 361-382.

Smith, K., Scarr, M., \& Scarpaci, C. (2010). Grey nurse shark (Carcharias Taurus) diving tourism: Tourist compliance and shark behavior at Fish Rock, Australia. Environmental Management, 46(5), 699-710.

Sparks, B. A., \& Browning, V. (2011). The impact of online reviews on hotel booking intentions and perception of trust. Tourism Management, 32(6), 1310-1323.

Stebbins, R. A. (2007). Serious leisure: A perspective for our time. New Brunswick, NJ: Transaction.

Stolk, P., Markwell, K., \& Jenkins, J. M. (2007). Artificial reefs as recreational scuba diving resources: A critical review of research. Journal of Sustainable Tourism, 15(4), 331-350.

Taun, Y. F. (1974). Topophilia: A study of environmental perception, attitudes, and values. Englewood Cliffs, NJ: Prentice-Hall.

Thapa, B., Graefe, A. R., \& Meyer, L. A. (2006). Specialization and marine based environmental behaviors among SCUBA divers. Journal of Leisure Research, 38(4), 601-615.

The Florida Keys \& Key West (n.d.). The Spiegel Grove wreck. Retrieved from https://fla-keys.com/diving/spiegel-grove/

Timothy, D. J. (2011). Cultural and heritage tourism: An introduction. Bristol, UK: Channel View Publications.

Tourism Bonaire. (2019). Diving. Retrieved from https:// www.tourismbonaire.com/bonaire-diving

Tsaur, S. H., Lin, W. R., \& Cheng, T. M. (2105). Toward a structural model of challenge experience in adventure recreation. Journal of Leisure Research, 47(3), 322-336.

Tynyakov, J., Rousseau, M., Chen, M., Figus, O., Belhassen, Y., \& Shashar, N. (2017). Artificial reefs as a means of spreading diving pressure in a coral reef environment. Ocean \& Coastal Management, 149, 159-164.

Tzanakis, M. (2016). Scuba diving as a practice of self. Loisir et Societe, 39(3), 451-466.

Uyarra, M. C., Watkinson, A. R., \& Cote, I. M. (2009). Managing dive tourism for the sustainable use of coral reefs: Validating diver perceptions of attractive site features. Environmental Management, 43(1), 1-16. 
Wakefield, L. T., \& Bennett, G. (2018). Sports fan experience: Electronic word-of-mouth in ephemeral social media. Sport Management Review, 21(2), 147-159.

Webb, E. J., Campbell, D. T., Schwartz, R. D., \& Sechrest, L. (2000). Unobstrusive measures. Thousand Oaks, CA: Sage.

Wilhelmsson, D., Öhman, M. C., Ståhl, H., \& Shlesinger, Y. (1998). Artificial reefs and dive tourism in Eilat, Israel. Ambio, 27(8), 764-766.

Wong, C. U., \& Qi, S. (2017). Tracking the evolution of a destination's image by text-mining online reviews-The case of Macau. Tourism Management, 23, 19-29.
Wong, K. M., Thirumoorthy, T., \& Musa, G. (2000). Scuba diving motivation. Studies, 60.

Wongthong, P., \& Harvey, N. (2014). Integrated coastal management and sustainable tourism: A case study of the reef-based SCUBA dive industry from Thailand. Ocean \& Coastal Management, 95, 138-146.

Xiang, Z., \& Gretzel, U. (2010). Role of social media in online travel information search. Tourism Management, 31(2), 179-188.

Zakai, D., \& Chadwick-Furman, N.E. (2002). Impacts of intensive recreational diving on reef corals at Eilat, northern Red Sea. Biological Conservation, 105, 179-187. 
Copyright of Tourism in Marine Environments is the property of Cognizant, LLC and its content may not be copied or emailed to multiple sites or posted to a listserv without the copyright holder's express written permission. However, users may print, download, or email articles for individual use. 